University of Nebraska - Lincoln DigitalCommons@University of Nebraska - Lincoln

U.S. Environmental Protection Agency Papers

U.S. Environmental Protection Agency

2014

\title{
A review of water use in the U.S. electric power sector: insights from systems-level perspectives
}

Rebecca S. Dodder

U.S. Environmental Protection Agency, dodder.rebecca@epa.gov

Follow this and additional works at: http://digitalcommons.unl.edu/usepapapers

Dodder, Rebecca S., "A review of water use in the U.S. electric power sector: insights from systems-level perspectives" (2014). U.S.

Environmental Protection Agency Papers. 213.

http://digitalcommons.unl.edu/usepapapers/213

This Article is brought to you for free and open access by the U.S. Environmental Protection Agency at DigitalCommons@University of Nebraska -

Lincoln. It has been accepted for inclusion in U.S. Environmental Protection Agency Papers by an authorized administrator of

DigitalCommons@University of Nebraska - Lincoln. 


\section{A review of water use in the U.S. electric power sector: insights from systems-level perspectives Rebecca S Dodder}

\begin{abstract}
Thermoelectric power production comprised $41 \%$ of total freshwater withdrawals in the U.S., surpassing even agriculture. This review highlights scenarios of the electric sector's future demands for water, including scenarios that limit both $\mathrm{CO}_{2}$ and water availability. A number of studies show withdrawals decreasing with retirement of existing electricity generating units. Consumption, the evaporative losses, also decreases in many scenarios. However, climate mitigation scenarios relying heavily on nuclear and carbon capture technologies may induce increases in water consumption. These increases in consumption represent a potential tradeoff between climate mitigation and adaptation of the electric sector to climate-related changes in water resources. It also points to the need for both analyses and technological solutions from the chemical engineering community.
\end{abstract}

\begin{abstract}
Addresses
U.S. Environmental Protection Agency, National Risk Management Research Laboratory, 109 T.W. Alexander Drive, Research Triangle
\end{abstract} Park, NC 27711, USA

Corresponding author: Dodder, Rebecca S (dodder.rebecca@epa.gov)

Current Opinion in Chemical Engineering 2014, 5:7-14

This review comes from a themed issue on Energy and environmental engineering

Edited by Rakesh Agrawal and Subhas K Sikdar

S2211-3398/\$ - see front matter, Published by Elsevier Ltd.

http://dx.doi.org/10.1016/j.coche.2014.03.004

\section{Introduction}

When discussing the water-energy nexus [1,2], the electric power sector stands out as a crucial link between water and energy systems. Thermoelectric power production has now surpassed agriculture as the largest withdrawer of fresh water in the U.S., comprising $41 \%$ of total withdrawals [3]. Water from fresh surface and groundwater sources, as well as saline and brackish sources, is used in electric power operations, which provide electricity to end-uses in the residential, commercial, industrial, and transportation sectors (Figure 1). Specific events in recent years have underscored the growing vulnerability of the electric power sector in the water-energy nexus. In 2007, drought in the Southeastern U.S. led to several facilities shutting down or reducing production. Hydroelectric facilities reduced power generation due to low flows on the Chattahoochee and other rivers, while elevated water temperatures led to reduced production at coal-fired and nuclear power plants $\left[4^{\circ \bullet}\right]$. Browns Ferry Nuclear Power Plant in Alabama has seen shutdown and idling of generators in 2007, 2008, 2011 and 2012 to avoid exceeding maximum temperatures of discharge water $\left[4^{\bullet \bullet}, 5\right]$. With drought and triple degree heat in Texas in 2011, the combination of heightened demand for electricity and unplanned plant outages led the Electric Reliability Council of Texas (ERCOT) to declare power emergencies $\left[4^{\bullet \bullet}, 5\right]$. In addition, low water levels at Texas power plant reservoirs reduced generation at one power plant and threatened to reduce or curtail production at other plants [6]. The 2003 heat wave and drought in Europe also affected power production and forced a number of plants to operate outside of their design limits $\left[7,8^{\bullet}, 9\right]$. There are also concerns in China with the boom in energy production potentially exacerbating the competition for limited water resources [10].

The concept of the water-energy nexus was highlighted twenty years ago in Gleick's seminal 1994 article [12], while efforts to forecast water use in the electric sector go back another twenty years earlier [13]. However, the growing catalog of water-related pressures and vulnerabilities of the electric power sector $\left[4^{\circ}{ }^{\circ}\right]$ has heightened the focus on the water demands for meeting current and future electricity demands in the context of global climate change [14]. In this review, I focus on analyses of water use by the U.S. electric sector, specifically the systems-level studies that attempt to quantify how electric sector water demands may change over the next several decades. As the literature has looked ahead to future water demands, studies have attempted to project water use in the context of global climate change and its implications for the water resources upon which the electric sector depends. Beyond the water-energy nexus, complex combinations of terms have become common, including the electricity-water-climate change nexus [15,16], electricity-water tradeoffs [17], CCS-water nexus [18], water- $\mathrm{CO}_{2}$ tradeoffs [ $19^{\circ}$ ], as well as the water-energyfood nexus [20] and even the society-biosphere-climateeconomy-energy system [21]. All of these combinations underscore the systems-level perspective as well as the diversity of modeling approaches that are used to quantify these linkages. This review will distil some of the insights and additional research questions emerging from this growing body of literature with a focus on questions of most relevance to the chemical engineering community.

\section{Water use in electric power generation}

Significant quantities of water are required for the operation of thermoelectric power plants $\left[22,23^{\bullet \bullet}\right]$, with the vast 
Figure 1

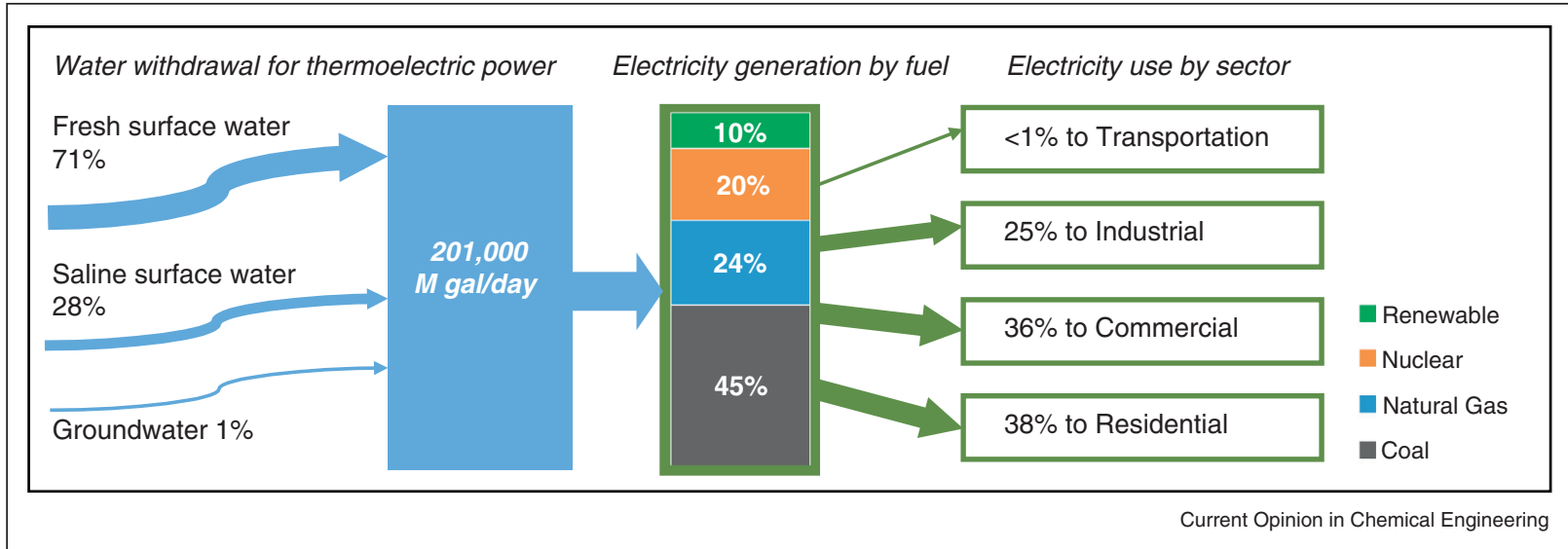

The water-energy nexus: water resources to electricity generation to end-use energy demands. Share of groundwater and surface water based on total thermoelectric-power water withdrawals in 2005, measured as million gallons per day (M gal/day) [3]. Updated estimated water use for 2010 will be available in late 2014 from USGS. Share of total electricity generation by fuel and end-use electricity sales by sector for 2010 from the Energy Information Administration (EIA) [11]. Note that water withdrawals would be only for nuclear, natural gas and coal, because the reported water withdrawals are for thermoelectric cooling.

majority of water used for cooling systems [4 $\left.4^{\bullet \bullet}, 24-26\right]$. Other water uses include process steam to drive turbines and operation of environmental control systems, such as flue gas desulfurization (FGD). Future use of carbon capture systems such as amine-based $\mathrm{CO}_{2}$ capture, would also require additional water use $\left[27^{\circ}\right]$. A number of water quality implications are related to the operation of power plants, as well as water impacts of the extraction and processing of primary energy resources such as coal and natural gas. I will focus here on water demands only from the operational phase of electric power generation, but will later discuss broader life cycle implications and related research directions.

To better evaluate the implications for water resources, electric power water use is measured in two ways: consumption and withdrawal. According to the U.S. Geological Survey (USGS), thermoelectric water consumption is 'the water evaporated or incorporated into by-products as a result of the production of electricity from heat,' and withdrawal is 'the water removed from groundwater or surface water for use in a thermoelectric power plant' $[3,28]$. Thermoelectric power plants have typically used two methods for condensing steam for electricity generation which have vastly different implications for withdrawals and consumption [23*0,24]. Earlier power plants built in the 1950 s to 1970 s typically used once-through or open-loop cooling systems that withdraw fresh or saline water from a river, lake, or ocean, then pass the water through the cooling system and return to the water body at a higher temperature. In the mid-1970s, power plants began to shift away from once-through systems to recirculating systems, with annual builds of once-through systems dropping precipitously [29]. Recirculating systems withdraw substantially less water, but have higher rates of evaporation (consumptive use) as the water is recirculated in a closed-loop with forced, induced or natural draft cooling towers. Dry cooling systems, as the name indicates, are air cooled, but can also be coupled with recirculating towers or ponds to form a hybrid system. Dry cooling and hybrid systems have recently surpassed once-through systems in terms of new installations [29].

Figure 2 provides a snapshot of the range of water withdrawals that are associated with different fuel, technology and cooling system combinations. The Energy Information Administration (EIA) has collected information reported by power plant operators for water consumption and withdrawals since 1985. However, these data have often had important discrepancies and inconsistencies, particularly when compared to calculated values [22,30]. Recent efforts have focused on consolidating and comparing calculated operational water use factors by fuel, technology and cooling system $\left[23^{\bullet \bullet}, 24\right]$. Figure 2 shows range of water withdrawals for a small subset of technologies, and illustrates the impact of cooling system choice on water use. Once-through cooling systems (Figure 2b) can be orders of magnitude higher than recirculating systems (cooling towers) (Figure 2a) for the same generation technologies, while dry systems and renewables (Figure 2a) have minimal water withdrawal needs. However, fuel and technology matter as well. The higher thermal efficiencies of natural gas combined cycle relative to a less efficient coal steam or nuclear facility translate into improved water efficiencies. This comparison is intended to highlight differences among some major fuel types/technologies and cooling systems, but does not represent the full range of withdrawal factors. For a 


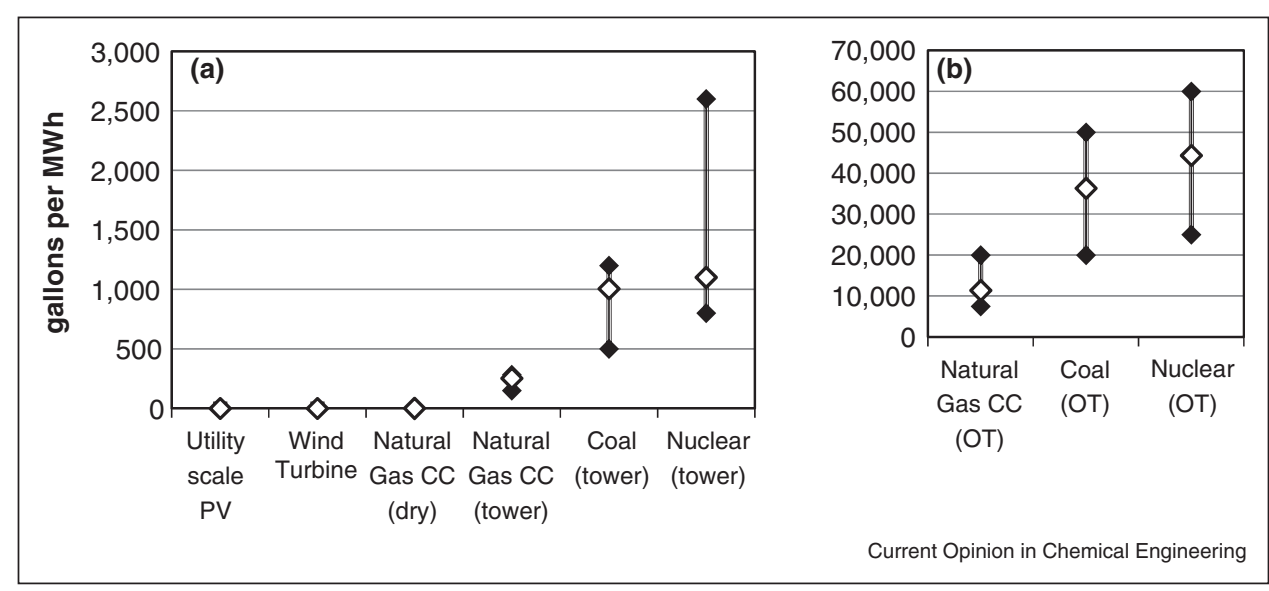

Water withdrawal factors (median, min, and max) (gallons per MWh) for selected combinations of fuel types and technologies for: (a) renewable power and thermoelectric systems with recirculating (tower) or dry cooling systems, and (b) thermoelectric power with once-through (OT) systems. $\mathrm{PV}=$ photovoltaic; $\mathrm{CC}=$ combined cycle. Note the difference in scale between recirculating and once-through systems. These factors represent withdrawal only. For water consumption, recirculating systems such as towers can have twice the consumption of once-through systems due to evaporative losses. Source: $\left[23^{\circ}\right]$.

comprehensive treatment of water withdrawal and consumption, with references to all primary literature from which the operational water use factors are derived, see $\left[23^{\bullet \bullet}, 24\right]$.

\section{Long-term system-level trends in water for energy}

Given the diversity of water withdrawal and consumption rates by technology class and cooling type, recent studies have attempted to quantify the impact of a changing electricity technology mix on aggregate water demands across the U.S. and for specific water-scarce regions within the U.S. Both 2012 and 2013 were exceptionally productive years for studies looking at the water-energy nexus for long-range scenarios of electricity generation $\left[8^{\bullet}, 18,19^{\bullet}, 31,32,33,34^{\bullet \bullet}, 35-38\right]$. Table 1 summarizes recent electricity-water studies using a range of modeling approaches, geographic scales and time horizons, and varying levels of linkage with water resources. In the remainder of this section, I will briefly discuss a subset of these studies and draw out some of the common trends and themes.

Earlier studies utilized existing projections for electricity mix coupled with the best available data on water factors to calculate the associated water demands out into the future [17,39]. In many cases, these studies were Annual Energy Outlook (AEO) reference cases or data on planned capacity expansions reported to the EIA. These studies attempted to provide a baseline for water demands out into the future. However, the emerging question was whether there were trade-offs or synergies between $\mathrm{CO}_{2}$ reductions from the electric sector and water demands, in other words, the climate-electricity-water nexus. On the one hand, the low water requirements for operation of non-thermoelectric renewable power, such as wind and solar PV, promised both low carbon and low water solutions (excluding water use and carbon emissions from the lifecycle perspective). On the other hand, reducing $\mathrm{CO}_{2}$ emissions through nuclear power, coal with carbon capture and sequestration (CCS) and even concentrating solar power (CSP) with wet cooling would imply higher water demands out into the future if relied upon heavily for reaching carbon reduction goals.

This interest in exploring the implications of carbon reductions in the electric sector motivated a number of researchers to explore a range of climate mitigation scenarios using different modeling platforms. Although not technically 'scenarios' in the same sense as the other analyses reviewed here, Cooper and Sehlke (2012) built on Pacala and Socolow's [49] seminal climate wedges proposal to identify the potential water use implications of GHG mitigation strategies or 'climate wedges' across the full energy system [41]. They included the water impacts of electricity generation-based mitigation wedges and suggested a number of water management strategies for reducing the impact on freshwater resources [41]. Chandel et al. (2011) used a modified version of EIA's National Energy Modeling System (NEMS) to analyze changes in the electric power mix under four climate policy scenarios represented by a price on carbon out to 2030 [40]. Relative to the reference case, freshwater withdrawals were reduced by up to $14 \%$, with higher carbon prices inducing the largest decreases in water withdrawals as existing units were retired. Consumption, however, increased under the high carbon price scenarios as water intensive CCS retrofits for coal came online. Tidwell et al. (2013) also assessed carbon constrained 


\section{Table 1}

Comparison of selected system-level studies of electric sector water demands.

\begin{tabular}{|c|c|c|c|c|c|c|}
\hline Study & $\begin{array}{l}\text { Model/Method } \\
\text { for energy }\end{array}$ & Geographic scope/scale & Time horizon & Mapping to water resources & Scenarios analyzed & Refs. \\
\hline Elcock 2010 & Based on AEO 2007 & U.S. & $2005-2030$ & $\begin{array}{l}\text { No, but assesses other } \\
\text { water demands }\end{array}$ & Reference case only & [39] \\
\hline Chandel et al., 2011 & NEMS & U.S., by NERC regions & $2005-2030$ & No & $\begin{array}{l}\text { Business as usual and four climate } \\
\text { policy scenarios }\end{array}$ & [40] \\
\hline Cooper and Sehlke 2012 & $\begin{array}{l}\text { AEO baseline and } \\
\text { 'mitigation wedges' }\end{array}$ & U.S. & N/A & No & $\begin{array}{l}\text { Mitigation wedges proposed by } \\
\text { Pacala and Socolow }\end{array}$ & [41] \\
\hline $\begin{array}{l}\text { Macknick et al. } 2013 \text { and } \\
\text { Clemmer et al. } 2013\end{array}$ & ReEDS & $\begin{array}{l}\text { U.S., ReEDS PCA regions } \\
\text { mapped to HUC2 regions. }\end{array}$ & $2010-2050$ & $\begin{array}{l}\text { Yes, link with WEAP model. } \\
\text { Case studies of SW [32,42] } \\
\text { and SE }[31,43] \text { U.S. }\end{array}$ & $\begin{array}{l}\text { Reference base and three carbon } \\
\text { budget scenarios with different } \\
\text { technology targets, including an } \\
\text { energy efficiency scenario }\end{array}$ & {$\left[34^{\bullet \bullet}, 37,44\right]$} \\
\hline $\begin{array}{l}\text { Davies et al. } 2013 \text { and } \\
\text { Kyle et al. } 2013\end{array}$ & GCAM & $\begin{array}{l}\text { Global, with } 14 \text { regions } \\
\text { including U.S. }\end{array}$ & 2005-2095 & No & $\begin{array}{l}\text { Scenarios include three futures of } \\
\text { climate mitigation policy and two } \\
\text { technology strategies }\end{array}$ & {$\left[35,36,45^{\bullet}, 46\right]$} \\
\hline Tidwell et al. 2013 & $\begin{array}{l}\text { System dynamics } \\
\text { architecture }\end{array}$ & U.S. at 6-digit HUC level & $2009-2035$ & $\begin{array}{l}\text { Thermoelectric and } \\
\text { non-thermoelectric } \\
\text { consumption mapped } \\
\text { to water availability }\end{array}$ & $\begin{array}{l}\text { Three energy futures, reference } \\
\text { case and two } \mathrm{CO}_{2} \text { prices, affected } \\
\text { capacity either retired or retrofitted } \\
\text { for CCS }\end{array}$ & [18] \\
\hline Webster et al. 2013 & $\begin{array}{l}\text { Capacity expansion } \\
\text { model }\end{array}$ & Texas (ERCOT) & $2005-2050$ & $\begin{array}{l}\text { No, but water limits } \\
\text { are modeled }\end{array}$ & $\begin{array}{l}\text { Monte Carlo analysis with } 1,000 \\
\text { simulations for scenarios of } \mathrm{CO}_{2} \\
\text { limits and combined } \mathrm{CO}_{2} \text { and } \mathrm{H}_{2} \mathrm{O} \\
\text { limits }\end{array}$ & {$\left[1^{\circ}\right]$} \\
\hline Ackerman and Fisher 2013 & $\begin{array}{l}\text { System dynamics } \\
\text { framework }\end{array}$ & Western U.S. (11 states) & $2008-2100$ & $\begin{array}{l}\text { No, but models impacts } \\
\text { of price on water }\end{array}$ & $\begin{array}{l}\text { Four scenarios, including limits on } \\
\text { carbon and water }\end{array}$ & [38] \\
\hline $\begin{array}{l}\text { Cameron 2013, } \\
\text { Dodder et al. } 2011\end{array}$ & $\begin{array}{l}\text { MARKAL energy } \\
\text { systems model }\end{array}$ & $\begin{array}{l}\text { U.S. by nine } \\
\text { Census Divisions }\end{array}$ & $2005-2055$ & No & $\begin{array}{l}\text { Four scenarios of energy system- } \\
\text { wide } \mathrm{CO}_{2} \text { reduction targets, with } \\
\text { sensitivity analysis by major } \\
\text { technology classes }\end{array}$ & {$[47,48]$} \\
\hline
\end{tabular}

Acronyms: NERC, North American Electricity Reliability Corporation; ERCOT, Electric Reliability Council of Texas; HUC, Hydrologic Unit Code; PCA, Power Control Area; ReEDS, Regional Energy Deployment System model; WEAP, Water Evaluation and Planning system; GCAM, Global Change Assessment Model; AEO, Annual Energy Outlook (various years); NEMS, National Energy Modeling

System; MARKAL (MARket ALlocation) energy systems model. 
futures with a focus on the role of CCS in meeting varying $\mathrm{CO}_{2}$ reduction goals [18]. Their bounding analysis considered either all affected capacity to be retired or retrofitted with CCS and found that for 2035 nationwide withdrawals could either increase $1 \%$ or decrease $60 \%$ relative to 2009 levels, but consumption could increase up to $21 \%$ or decrease $28 \%$. A recent set of studies using the Global Change Assessment Model (GCAM), an integrated assessment model of energy, agriculture and climate changes, also assessed water demands for electricity at the global level, but with a regional level of resolution that also provides insights into U.S. water demands $\left[35,36,45^{\circ}\right]$. The crucial role of turnover of existing once-through capital stock in the electric sector in reducing withdrawals was also emphasized.

One major effort that brought together researchers from multiple institutions, including academic (University of Texas at Austin; University of Colorado, Boulder), nongovernmental (Union of Concerned Scientists), and the National Renewable Energy Laboratory, was the Energy and Water in a Warming World (EW3) initiative. This collaboration has led to a number of reports [50,51] and journal articles, many of which were published in a Focus Issue of Environmental Research Letters: Focus on Electricity, Water and Climate Connections. This issue provides perhaps the most comprehensive and integrated effort to assess the water implications of electric power generation in the U.S., both at the national level and also with a high enough level of spatial resolution to assess watershed-level impacts. This issue includes the following sets of analyses: (a) a review of water factors from the primary literature $\left[23^{\circ \bullet}\right]$ and comparison of reported and calculated water use [22]; (b) description of a linked energy and water modeling framework (ReEDS and WEAP) [44]; (c) modeling of low carbon electricity futures [37], with assessment of the water impacts of those scenarios at the national and regional level $\left[34^{\bullet \bullet}\right]$; and (d) linking the results of the electricity scenarios with models of regional water systems for the southeastern U.S. [31,43] and southwestern U.S. [32,42].

Despite the range of modeling approaches and scales, several common themes have begun to emerge from these systems-level studies of electric sector water demands.

- Under a baseline scenario, water withdrawals are generally anticipated to decrease over the next several decades, relative to current water use. Driving this trend is the turnover of existing electric power plants, particularly the retirement of lower efficiency facilities with once-through cooling systems being replaced by higher efficiency facilities with recirculating systems.

- At both the national and regional level, reductions in withdrawals can occur simultaneously with increases in consumption, due to switching to recirculating systems with higher consumptive losses through evaporation.
- Under carbon mitigation scenarios, retirements are accelerated in the early years, potentially leading to even more precipitous declines in withdrawals.

- Under climate mitigation scenarios, the role of CCS technologies relative to the penetration of renewable power, such as solar PV and wind turbines, is a crucial determinant of the longer term trends in water use. In particular, reliance upon coal with CCS, as well as expansion of nuclear capacity, can potentially lead to increases in water consumption, even relative to current consumption levels.

- Global and national level trends do not necessarily translate into similar patterns at a regional or local scale. Depending upon the existing energy mix, cost and performance of future technologies, regional resource base, and future demands for electricity, changes in the regional electricity generation mix may either increase or decrease water consumption $\left[19^{\bullet}, 34^{\bullet \bullet}, 36,40\right]$.

- Although the primary focus of most of these studies has been to understand the drivers and implications of different electricity generation mixes, some of these studies also looked at demand side issues, such as the impact of end-use efficiency measures. Yet, demand side issues remain a somewhat unexplored topic. We lack assessments of how regional and temporal (i.e., seasonal and time of day) changes in electricity demand - due to demographic shifts, climate-related changes in residential/commercial heating and cooling needs, and increased electrification of transportation and other end-uses [47] — translate into changes in water demands.

\section{Some missing pieces in the water-energy puzzle}

Together, these studies have made enormous progress in assessing water withdrawal and consumption for the major water users in the electric power sector, principally, thermoelectric cooling (including coal, natural gas, biomass-based, geothermal and CSP, but also non-thermoelectric renewable electricity (such as wind and solar). Nevertheless, some gaps and research needs remain.

With regard to renewable power, the uncertainty in the consumptive water use of hydroelectric facilities is substantial with estimates ranging from 0 to 18,000 gallons per MWh [26]. This uncertainty has been 'singularly problematic' [36] both for studies that estimate water use factors by type of electric power generation and for studies that extrapolate the aggregate water demands for energy scenarios based on those factors. Issues include estimation of evaporative losses at reservoirs and allocation of those losses to power generation relative to other agricultural, recreational, and municipal uses of the reservoir. Many of the modeling approaches discussed in the previous section, such as the ReEDS and GCAM analyses, either excluded or treated as a separate category the water consumption of hydropower from their estimates of overall water demand. However, some related studies 
have tackled this issue by using estimates of water consumption and withdrawal (or 'manipulation') for hydroelectric power in their scenarios, particularly when the focus has been on ecological impacts, including issues such as fish species endangerment [52].

In terms of non-hydropower renewable electricity, energy storage technologies (e.g., batteries) may be an important aspect of scenarios with large increases in solar PV or wind generation. Improvements in battery technologies can support higher penetration of intermittent renewable power and, by extension, may play an important supporting role in the water-electricity nexus. How breakthroughs in storage technologies would affect water use and the vulnerability or resilience of the electric sector to changes in water resources is an open question.

Carbon capture and sequestration will be an area where continued analysis and R\&D are needed both to assess and also to improve the overall water performance of these systems-by reducing both the plant water use for cooling via a decreased parasitic load and the additional water needs of amine-based carbon capture, which can effectively double the water use (consumption and withdrawal) of a recirculating (wet tower) system [27 $7^{\circ}$. As highlighted in a number of studies $\left[18,34^{\bullet \bullet}, 40,47\right]$, carbon mitigation scenarios generally show reduction in water use, mainly withdrawal, in the near term with the retirement of existing plants. However, growing shares of water-intensive CCS for coal-based generation could counteract those early gains, in particular for water consumption. Improvements in overall thermal efficiency, integrated water management strategies, reuse and recycling of plant water and use of alternative water sources can ease the stress on local freshwater resources [53]. Zhai et al. (2011) emphasize that 'lowering plant water use needs to be explicitly considered in R\&D programs for advanced carbon capture technologies for pulverized coal (PC) power plants' $\left[27^{\circ}\right]$. This observation is relevant not only for coal with CCS but also for carbon capture technologies for natural gas-based generation, which in one analysis were shown to be more economically feasible in a combined $\mathrm{CO}_{2}$ and water-constrained scenario [19 $\left.{ }^{\circ}\right]$.

Combined heat and power (CHP) is an area that has typically garnered less attention in the water-energy literature. Nonetheless, CHP could provide opportunities for improvements in energy efficiency, reducing industrial sector electricity demand (see Figure 1) and thus indirectly reducing pressure on water resources $\left[34^{\circ \bullet}\right]$. Industrial steam systems, in general, have major data gaps with respect to fresh water consumption as data collection efforts, such as those by the USGS have typically not covered industrial level water use at a high level of detail for different manufacturing sectors or process technologies. However, an analysis of industrial steam systems calculated that water consumption represented $11 \%$ of total U.S. manufacturing water consumption. Moreover, food, paper, petroleum refining and chemicals industries accounted for nearly all of the freshwater consumption for steam, making these specific sectors 'attractive targets' for combined water and energy efficiency improvements [54].

Finally, this review has focused on the systems-level issues of the nexus between electric power generation and water resources. However, a complementary and important area of research is Life Cycle Assessment (LCA), an area that chemical engineers are well positioned to support $[55,56]$. Both energy systems studies and LCA can leverage and contribute to the development of more reliable data on water consumption and withdrawals for different electricity generation processes, including CCS and CHP, but also upstream processes for resource extraction, transportation and processing $\left[57^{\circ}, 58\right]$. Together, these types of studies can provide a more balanced picture of the full water footprint of electricity demands out into the future.

\section{Conclusions}

The purpose of this review was to provide a systems-level perspective and describe the context in which additional research and new solutions are needed from the community of chemical engineering researchers and practitioners. The list below, while not exhaustive, summarizes some important and emerging research needs:

- Continued improvement in water use factors, in particular for technologies and processes such as carbon capture and sequestration.

- Research and development of low-carbon and lowwater technologies, including renewable power with inherently low water demands (and associated technologies such as storage), and carbon capture technologies with lower overall freshwater requirements.

- Expanding the consideration of the water-energy nexus to other systems such as industrial steam systems and combined heat and power.

- Improvements in characterizing the water use of processes along the full lifecycle, from resource extraction and fuel processing to power plant construction and operation.

These efforts will advance our understanding of the water-energy nexus and help support mitigation strategies that do not compromise the ability of the electric sector to adapt to future climate changes.

\section{Disclaimer}

Conclusions presented in this paper are those of the author, do not necessarily represent, and shall not be interpreted to represent the position of EPA. 


\section{References and recommended reading}

Papers of particular interest, published within the period of review, have been highlighted as:

- of special interest

$\bullet \bullet$ of outstanding interest

1. Schnoor JL: Water-energy nexus. Environ Sci Technol 2011, 45:5065.

2. Gentleman DJ: Water|energy energy/water. Environ Sci Technol 2011, 45:4194.

3. Kenny JF, Barber NL, Hutson SS, Linsey KS, Lovelace JK, Maupin MA: Estimated use of water in the United States in 2005: U.S. Geological Survey Circular 1344. 2009. Last accessed 02-28-14 at: pubs.usgs.gov/circ/1344/

4. U.S. Department of Energy: U.S. Energy Sector Vulnerabilities to

-. Climate Change and Extreme Weather, DOE/PI-0013. . Last accessed 28-02-14 at: www.energy.gov/sites/prod/files/2013/07/ f2/20130716-

Energy\%20Sector\%20Vulnerabilities\%20Report.pdf U.S.

Department of Energy; 2013.

This report provides a comprehensive overview of the vulnerabilities of the electric sector and the broader energy system to climate change and extreme weather events, including details on specific events that have affected the electric power sector in recent years.

5. Scanlon BR, Duncan I, Reedy RC: Drought and the waterenergy nexus in Texas. Environ Res Lett 2013, 8:045033.

6. Fowler T: More power plants woes likely if Texas drought drags into winter. In Fuelfix, powered by CH2MHill Oil \& Gas. 2011. Last accessed 28-02-14 at: fuelfix.com/blog/2011/08/24/more-powerplant-woes-likely-if-texas-drought-drags-into-winter/

7. van Vliet MTH, Vögele $S$, Rübbelke D: Water constraints on European power supply under climate change: impacts on electricity prices. Environ Res Lett 2013, 8:03501.

8. van Vliet MTH, Yearsley JR, Ludwig F, Vogele S, Lettenmaier DP,

- Kabat P: Vulnerability of US and European electricity supply to climate change. Nature Clim Change 2012, 2:676-681.

This article highlights the types of changes in water resources that will affect the vulnerability of electric power production, primarily changes in low river flows and river water temperature.

9. Fink AH, Brücher T, Krüger A, Leckebusch GC, Pinto JG, Ulbrich U: The 2003 European summer heatwaves and drought-synoptic diagnosis and impacts. Weather 2004, 59:209-216.

10. Zhang C, Anadon LD: Life cycle water use of energy production and its environmental impacts in China. Environ Sci Technol 2013, 47:14459-14467.

11. Energy Information Administration: Annual Energy Outlook 2013. U.S. Department of Energy; 2013.

12. Gleick PH: Water and energy. Annu Rev Energy Environ 1994, - 19:267-299.

A classic description of the bidirectional water and energy nexus.

13. Young HP, Thompson RG: Forecasting water use for electric power generation. Water Resour Res 1973, 9:800-807.

14. Miller CA: 3.02 - Energy resources and policy: vulnerability of energy resources and resource availability - fossil fuels (oil, coal, natural gas, oil shale). In Climate Vulnerability. Edited by Pielke. Academic Press; 2013:37-51.

15. Nanduri V, Otieno W: A new water and carbon conscious electricity market model for the electricity-water-climate change nexus. Electr J 2011, 24:64-74.

16. Nanduri V, Saavedra-Antolínez I: A competitive Markov decision process model for the energy-water-climate change nexus. Appl Energy 2013, 111:186-198.

17. Sovacool BK, Sovacool KE: Identifying future electricity-water tradeoffs in the United States. Energy Policy 2009, 37:27632773.

18. Tidwell VC, Malczynski LA, Kobos PH, Klise GT, Shuster E: Potential impacts of electric power production utilizing natural gas, renewables and carbon capture and sequestration on U.S. freshwater resources. Environ Sci Technol 2013, 47:8940-8947.

19. Webster M, Donohoo $\mathrm{P}$, Palmintier $\mathrm{B}$ : Water- $\mathrm{CO}_{2}$ trade-offs in - electricity generation planning. Nature Clim Change 2013, 3:1029-1032.

This study adds a unique context to the other energy systems studies by incorporating uncertainty analysis to estimates of $\mathrm{CO}_{2}$ emissions and water use, in the context of a particular energy system (Texas).

20. Bazilian M, Rogner H, Howells M, Hermann S, Arent D, Gielen D, Steduto P, Mueller A, Komor P, Tol RSJ, Yumkella KY: Considering the energy, water and food nexus: towards an integrated modelling approach. Energy Policy 2011, 39:78967906.

21. Akhtar MK, Wibe J, Simonovic SP, MacGee J: Integrated assessment model of society-biosphere-climate-economyenergy system. Environ Model Softw 2013, 49:1-21.

22. Averyt K, Macknick J, Rogers J, Madden N, Fisher J, Meldrum J, Newmark R: Water use for electricity in the United States: an analysis of reported and calculated water use information for 2008. Environ Res Lett 2013, 8:015001.

23. Macknick J, Newmark R, Heath G, Hallett KC:: Operational water -• consumption and withdrawal factors for electricity generating technologies: a review of existing literature. Environ Res Lett 2012, 7:045802.

Along with the Macknick et al., 2011 report, this article is a comprehensive review of water use for all major electricity generation technologies, also providing linkages to the primary literature from which these factors are derived. A number of other studies rely on these factors, directly or in a modified form.

24. Macknick J, Newmark R, Heath G, Hallett KC: A review of operational water consumption and withdrawal factors for electricity generating technologies, NREL/TP-6A20-50900. National Renewable Energy Laboratory; 2011:. Last accessed 2802-14 at: www.nrel.gov/docs/fy110sti/50900.pdf.

25. National Energy Technology Laboratory Estimating freshwater needs to meet future thermoelectric generation requirements, 2010 update. DOE/NETL-400/2010/1339. U.S. Department of Energy; 2010. Last accessed 28-02-14 at: www.netl.doe.gov/ energy-analyses/pubs/2010_Water_Needs_Analysis.pdf.

26. Torcellini P, Long N, Judkoff R: Consumptive water use for U.S. power production, NREL/TP-550-33905. National Renewable Energy Laboratory; 2003. Last accessed 28-02-14 at: www.nrel.gov/docs/fy04osti/33905.pdf.

27. Zhai H, Rubin ES, Versteeg PL: Water use at pulverized coal

- $\quad$ power plants with postcombustion carbon capture and storage. Environ Sci Technol 2011, 45:2479-2485.

Excellent resource to understand water use implications of coal-fired power plants with carbon capture and storage, including different boiler types and cooling technologies.

28. Diehl TH, Harris M, Murphy JC, Hutson SS, Ladd DE: Methods for estimating water consumption for thermoelectric power plants in the United States, USGS Scientific Investigations Report: 20135188. U.S. Geologic Services; 2013. Last accessed 28-02-14 at: pubs.usgs.gov/sir/2013/5188/.

29. Energy Information Administration: Many newer power plants have cooling systems that reuse water. In Today in Energy, February 12. U.S. Department of Energy; 2014. Last accessed 2802-14 at: www.eia.gov/todayinenergy/detail.cfm?id=14971.

30. U.S. Government Accountability Office: Energy-water nexus: improvements to Federal water use data would increase understanding of trends in power plant water use: Report to the Chairman, Committee on Science and Technology, House of Representatives, GAO-10-23. 2009. Last accessed 28-02-14 at: www.gao.gov/products/GAO-10-23.

31. Yates D, Meldrum J, Flores-Lopez F, Michelle D: Integrated impacts of future electricity mix scenarios on select southeastern US water resources. Environ Res Lett 2013, 8:035042.

32. Yates D, Meldrum J, Averyt K: The influence of future electricity mix alternatives on southwestern US water resources. Environ Res Lett 2013, 8:045005. 
33. Roy SB, Chen L, Girvetz EH, Maurer EP, Mills WB, Grieb TM: Projecting water withdrawal and supply for future decades in the U.S. under climate change scenarios. Environ Sci Technol 2012, 46:2545-2556.

34. Macknick J, Sattler S, Averyt K, Clemmer S, Rogers J: The water

-• implications of generating electricity: water use across the United States based on different electricity pathways through 2050. Environ Res Lett 2012, 7:045803.

This study, along with the other companion studies in the Focus Issue of Environmental Research Letters, highlights the key dynamics over time, at the US and regional level, for both consumption and withdrawal under a range of climate mitigation scenarios.

35. Dooley JJ, Kyle P, Davies EGR: Climate mitigation's impact on global and regional electric power sector water use in the 21st century. Energy Procedia 2013, 37:2470-2478.

36. Davies EGR, Kyle P, Edmonds JA: An integrated assessment of global and regional water demands for electricity generation to 2095. Adv Water Resour 2013, 52:296-313.

37. Clemmer S, Rogers J, Sattler S, Macknick J, Mai T: Modeling lowcarbon US electricity futures to explore impacts on national and regional water use. Environ Res Lett 2013, 8:015004.

38. Ackerman F, Fisher J: Is there a water-energy nexus in electricity generation? Long-term scenarios for the western United States. Energy Policy 2013, 59:235-241

39. Elcock D: Future U.S. water consumption: the role of energy production. JAWRA J Am Water Resour Assoc 2010, 46:447-460.

40. Chandel MK, Pratson LF, Jackson RB: The potential impacts of climate-change policy on freshwater use in thermoelectric power generation. Energy Policy 2011, 39:6234-6242.

41. Cooper DC, Sehlke G: Sustainability and energy development: influences of greenhouse gas emission reduction options on water use in energy production. Environ Sci Technol 2012 46:3509-3518.

42. Yates D, Averyt K, Flores-Lopez F, Meldrum J, Sattler S, Sieber J, Young C: A water resources model to explore the implications of energy alternatives in the southwestern US. Environ Res Lett 2013, 8:045004.

43. Flores-López F, Yates D: A water system model for exploring electric energy alternatives in southeastern US basins. Environ Res Lett 2013, 8:035041.

44. Sattler S, Macknick J, Yates D, Flores-Lopez F, Lopez A, Rogers J: Linking electricity and water models to assess electricity choices at water-relevant scales. Environ Res Lett 2012 7:045804.

45. Kyle P, Davies EGR, Dooley JJ, Smith SJ, Clarke LE, Edmonds JA,

- Hejazi M: Influence of climate change mitigation technology on global demands of water for electricity generation. Int $J$ Greenhouse Gas Contr 2013, 13:112-123.

This study provides a global perspective on water demand for electricity generation.

46. Hejazi M, Edmonds J, Clarke L, Kyle P, Davies E, Chaturvedi V, Wise M, Patel P, Eom J, Calvin K et al.: Long-term global water projections using six socioeconomic scenarios in an integrated assessment modeling framework. Technol Forecast Social Change 2014, 81:205-226.

47. Cameron $\mathrm{CM}$ : The impact of future $\mathrm{CO}_{2}$ emission reduction targets on U.S. electric sector water use. Department of Environmental Sciences and Engineering. University of North Carolina at Chapel Hill; 2013:. Masters Thesis.

48. Dodder R, Felgenhauer T, King C, Yelverton W: Water and greenhouse gas tradeoffs associated with a transition to a low carbon transportation system. In Proceedings of the ASME 2011 International Mechanical Engineering Congress \& Exposition Denver, CO: 2011.

49. Pacala S, Socolow R: Stabilization wedges: solving the climate problem for the next 50 years with current technologies. Science 2004, 305:968-972.

50. Averyt K, Fisher J, Huber-Lee A, Lewis A, Macknick J, Madden N, Rogers J, Tellinghuisen S: Freshwater use by U.S. power plants: electricity's thirst for a precious resource. A report of the Energy and Water in a Warming World initiative. Cambridge, MA: Union of Concerned Scientists; 2011. Last accessed 02-29-14 at: www.ucsusa.org/assets/documents/clean_energy/ew3/ew3freshwater-use-by-us-power-plants.pdf.

51. Rogers J, Averyt K, Clemmer S, Davis M, Flores-Lopez F, Frumhoff P, Kenney D, Macknick J, Madden N, Meldrum J et al.: Water-smart Power: Strengthening The U.S. Electricity System in a Warming World. Cambridge, MA: Union of Concerned Scientists; 2013, .. Last accessed 02-29-14 at: www.ucsusa.org/assets/ documents/clean_energy/Water-Smart-Power-Full-Report.pdf.

52. McDonald RI, Olden JD, Opperman JJ, Miller WM, Fargione J, Revenga C, Higgins JV, Powell J: Energy, water and fish: biodiversity impacts of energy-sector water demand in the United States depend on efficiency and policy measures. PLoS One 2012:7.

53. Court B, Celia MA, Nordbotten JM, Elliot TR: Active anc integrated management of water resources throughout $\mathrm{CO}_{2}$ capture and sequestration operations. Energy Procedia 2011, 4:4221-4229.

54. Walker ME, Lv Z, Masanet E: Industrial steam systems and the energy-water nexus. Environ Sci Technol 2013, 47:13060-13067.

55. Provo J, Fava J, Baer S: Life Cycle Assessment and the chemical engineer: a marriage of convenience. Curr Opin Chem Eng 2013, 2:278-281.

56. Curran MA: Life Cycle Assessment: a review of the methodology and its application to sustainability. Curr Opin Chem Eng 2013, 2:273-277.

57. Meldrum J, Nettles-Anderson S, Heath G, Macknick J: Life cycle

- water use for electricity generation: a review and harmonization of literature estimates. Environ Res Lett 2013, 8:015031.

This provides an updated review of water use across the full lifecycle for electricity generation.

58. Grubert EA, Beach FC, Webber ME: Can switching fuels save water? A life cycle quantification of freshwater consumption for Texas coal- and natural gas-fired electricity. Environ Res Lett 2012, 7:045801. 